J. Perinat. Med. 7 (1979) 215

Computing techniques for intrapartum physiological data reduction. II. Fetal heart rate

\author{
M. J. Henry, D. D. F. McColl, J. W. Crawford, N. Patel
}

Obstetric Computing Laboratory, Ninewells Hospital and Medical School, Dundee/ Scotland

Routine interpretation of Fetal Heart Rate (FHR) changes seeks to detect the occurrence of fetal distress. It has its basis in the pioneering work of CALDEYRo-BARCIA et al. [2] and Hon and QUILLIGAN [7], to which has been added the contributions of numerous workers, as reviewed by OTT [9].

Several components of FHR tracings have been described: Baseline FHR level, Transient Accelerations, Transient Decelerations (Dips) and Baseline Variability; however, there is much confusion over definition, aetiology and significance of these components.

Computing techniques have been employed to help clarify definitions [3]; describe and evaluate deceleration parameters [8]; measure and evaluate various deceleration areas or 'dip areas' $[1,11,12]$ and investigate FHR variability [4], however, they were not designed for routine real-time clinical usage.

Many of the computer systems which have been developed for real-time clinical use have favoured calculation of a single index of FHR activity, together with detection of various 'alarm' conditions based on baseline FHR level. Deceleration area was used with an on-line computer by FLOWERS et al. [5] and GibBons and JoHNSON [6] as an index of FHR activity but had the limitation that it only described one component of FHR activity.

It appeared that there was a requirement for development of a method which would: 1) Reduce the large quantities of FHR data, usually output as a chart recording, to a compact but comprehensive overall description of FHR activity. 2) allow various components of FHR activity to be assessed. 3) allow the clinician to identify those portions of data which require more detailed appraisal 4) perhaps most importantly, allow the clinician to identify large parts of many FHR tracings which all clinicians would agree showed patterns which are completely normal.

\section{FHR measurement}

FHR measurement is performed by a program known as the Software Ratemeter which calculates beat to beat time intervals from the filtered fetal ECG (FECG) signal derived from a scalp electrode. Once the FECG signal has been filtered to remove low frequency variations it is sampled at a frequency of 1000 hertz.

The Software Ratemeter operates in three distinct stages: 1) Amplitude Threshold Calculation, where the FECG signal is examined to determine the optimum level and polarity of the threshold above which only R-wave peaks occur. 2) Detection of the R-wave peaks and calculation of the time interval between succeeding peaks. 3) Adaptation of the amplitude threshold to changes in amplitude and 'signal to noise ratio' $(\mathrm{S} / \mathrm{N})$ of the FECG signal.

When automation is built into analysis methods it becomes vital that the authenticity of each beat to beat interval is validated and artefactual ones re- 
jected. A high proportion of invalid intervals can be rejected using fairly simple techniques: a) For the purposes of data validation, any interval lying outside the range 300 to 1200 milliseconds (50 to $200 \mathrm{bpm}$ ) is deemed to be invalid. b) Fluctuating amplitude can cause an R-wave or several $\mathrm{R}$-waves to be missed. This is manifest in the occurrence of doubled or tripled intervals.

$\mathrm{I}(\mathrm{n})$ is doubled if: $|\mathrm{I}(\mathrm{n})-2 . \mathrm{I}(\mathrm{n}-1)|<10 \%$. I(n-1) and tripled if: I I(n)-3.I (n-1) $i<20 \%$.I(n-1)

c) Mistriggering of the software ratemeter can occur in the presence of spurious noise pulses which cross the amplitude threshold. If all of the following are found to be true, then $I(n)$ and $I(n+1)$ are rejected:

I) $|\mathrm{I}(\mathrm{n}-1)-\mathrm{I}(\mathrm{n})|>10 \% . \mathrm{I}(\mathrm{n}-1)$

II) $|\mathrm{I}(\mathrm{n})-\mathrm{I}(\mathrm{n}+1)|$ or $\mathrm{I}(\mathrm{n}+1)-\mathrm{I}(\mathrm{n}+2) \mid>10 \%$. $\mathrm{I}(\mathrm{n}-1)$

III) $|\mathrm{I}(\mathrm{n}-1)-\mathrm{I}(\mathrm{n}+2)|<5 \% . \mathrm{I}(\mathrm{n}-1)$

Multiple mistriggering is usually detected by the upper limit testing in a).

\section{Rate histogram generation}

Generation of the frequency distribution or histogram of beat to beat intervals was first used for investigation of adult cardiac rhythms, for example, Sim Borg et al. [10].

The Rate Histogram (RH) is formed by generating an array of columns, or 'bins', each corresponding to a range of instantaneous heart rates. Each valid beat to beat interval, from the Software Ratemeter, is converted to its equivalent instantaneous FHR, and the count in the corresponding bin is incremented.

An example of a rate histogram is shown in Fig. 1 together with the corresponding ten minutes of chart recording. The RH has 62 bins, each with a range of $2 \mathrm{bpm}$, and is so arranged that rates in the range 80 to $200 \mathrm{bpm}$ can be accommodated.

In order to convert the beat to beat interval function to a rate function, (as represented by a chart recording) linear weighting is applied to each bin as: $\mathrm{Wr}=(200 . \mathrm{Nr}) / \mathrm{r}$, where $\mathrm{r}$ is the lower limit of the bin in bpm; $\mathrm{Nr}$ is the unweighted count in the bin with lower limit $\mathrm{r}$; and $\mathrm{Wr}$ is the weighted count.

\section{Examples of histograms,}

The tracing in Fig. 1 is a 'normal' one, in that it does not exhibit any marked transient changes and both the baseline level and variability are acceptable, the corresponding histogram is also 'normal' in appearance.

Fig. 2 shows examples of transient accelerations; the corresponding histogram is skewed towards the higher rates.

Fig. 3 illustrates some decelerations with moderate amplitudes, the corresponding histogram is skewed towards the lower rates.

The potentially worrying occurrence of reduced baseline variability is illustrated in Fig. 4.

\section{Descrip tive parameters}

Several of the Rate Histogram's parameters can be used to provide a concise description of FHR activity during a specific epoch.

a) Baseline FHR level

The value of the MODE (most common value) of the $\mathrm{RH}$ provides a reasonably accurate assessment of the baseline level, when compared with visual analysis of the chart recording. However, those epochs in which the baseline is not clear must be catered for.

The percentage of counts in the modal and two adjacent bins, termed the MODAL PERCENTAGE, has been found to provide a reasonable assessment of the validity of the mode as a measure of baseline level.

MODALPERCENTAGE $=\frac{W 1+W m+W n}{W t-W 100} \times 100 \%$

where $\mathrm{Wm}$ is the number of counts in the modal bin of the weighted $\mathrm{RH}, \mathrm{W} 1$ and $\mathrm{Wn}$ are the counts in the bins on either side of the modal bin. Wt is the total number of counts in the histogram. W100 is the number of counts in those bins representing rates less than $100 \mathrm{bpm}$, and provides for those epochs having severe deceleration activity by artificially increasing the Modal Percentage.

b) Acceleration activity is measured as:

5 th CENTILE-MODE in bpm. 


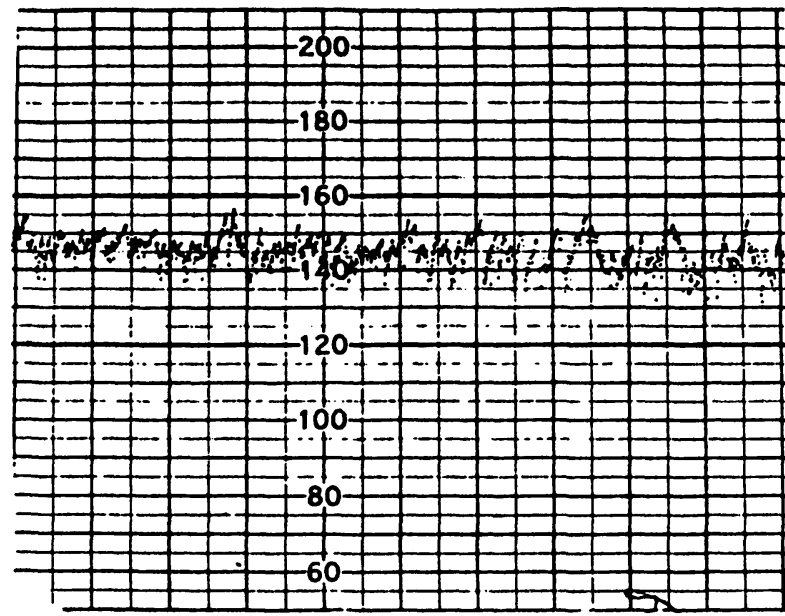

RATEGRAM

REPRESENTATION

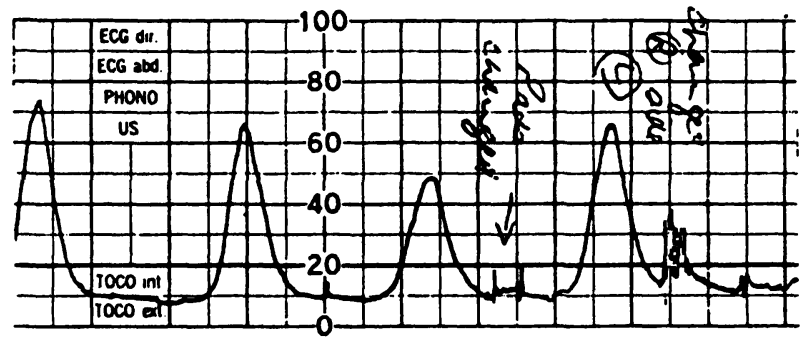

$150 \uparrow:$

$145 T X$

$140 \uparrow$.

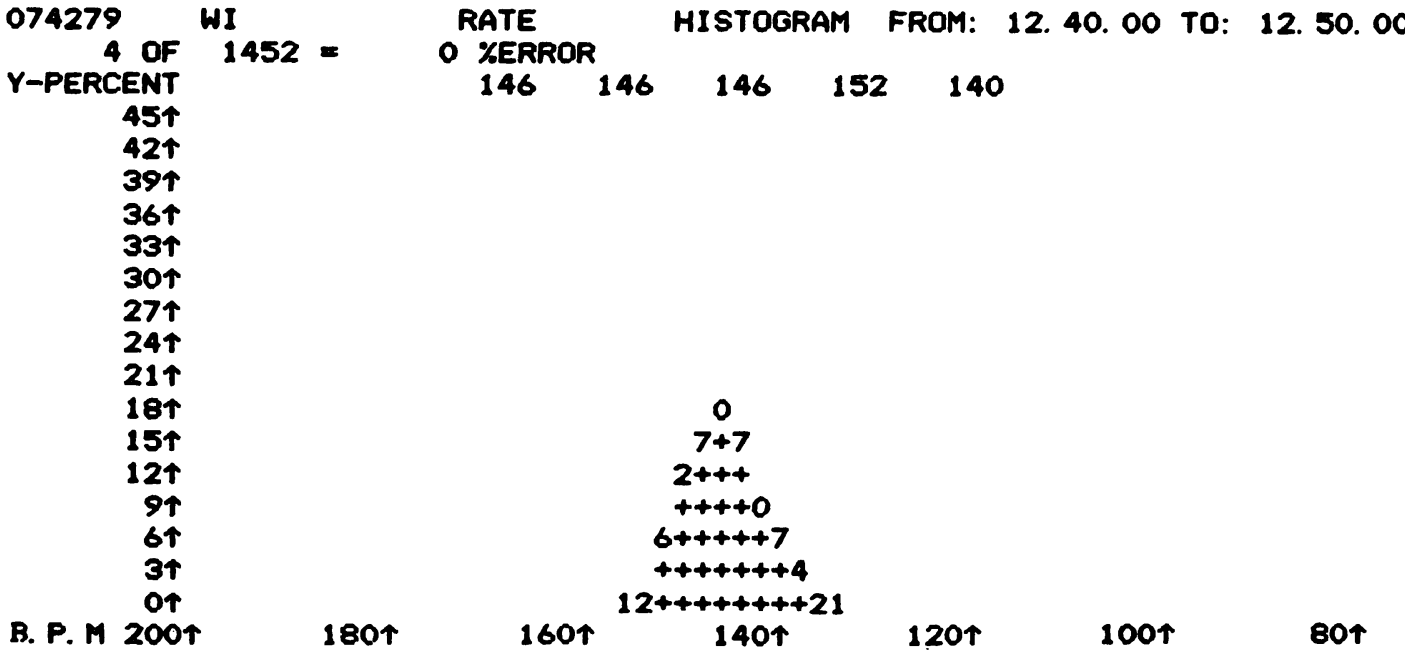

Fig. 1. 'NORMAL' FHR. Chart recording, Rate Histogram (RH) and Rategram representation of FHR activity during the ten minute epoch starting at 12.40, epoch $1 \mathrm{~A}$ of Fig. 5. Line 3 of the RH shows its descriptive parameters in the order: Mode, Mean, Median, 5 th Percentile, 90 th Percentile.

c) Similarly, deceleration activity is measured as: MODE-90 th CENTILE in bpm.

d) Baseline Variability

Occurrence of reduced variability can be an ominous sign, so that in general, the obstetrician is interested in 'narrowing' or 'smoothing' of the chart recorder trace.

5 th CENTILE-90th CENTILE, can be used to measure decrease in the amplitude of variability, although it does not reflect changes in the frequency of the variation. 


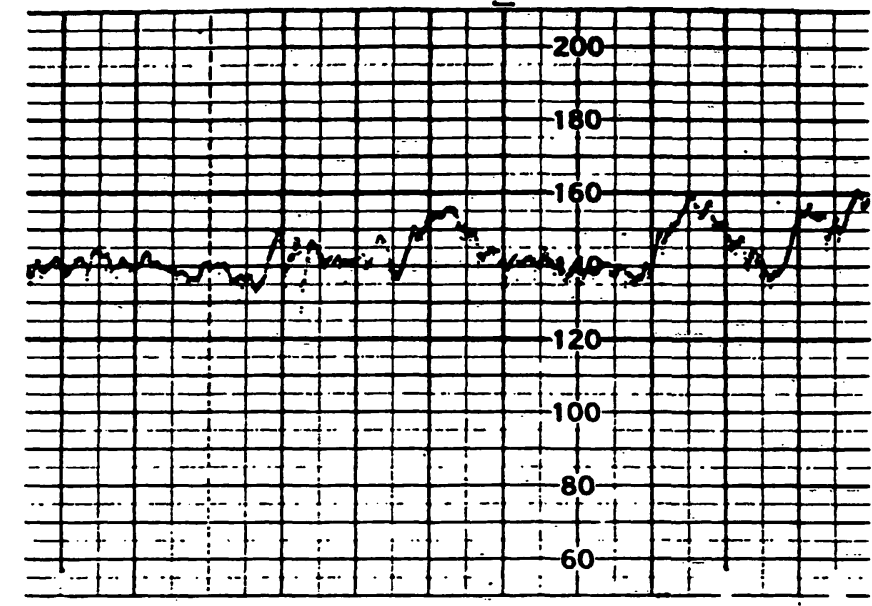

RATECaAar

iAEPRESENTATION

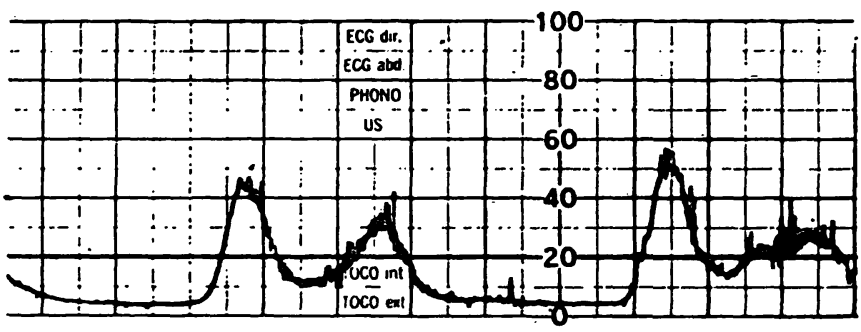

15ST :

1501:

$1455:$

$140+x$
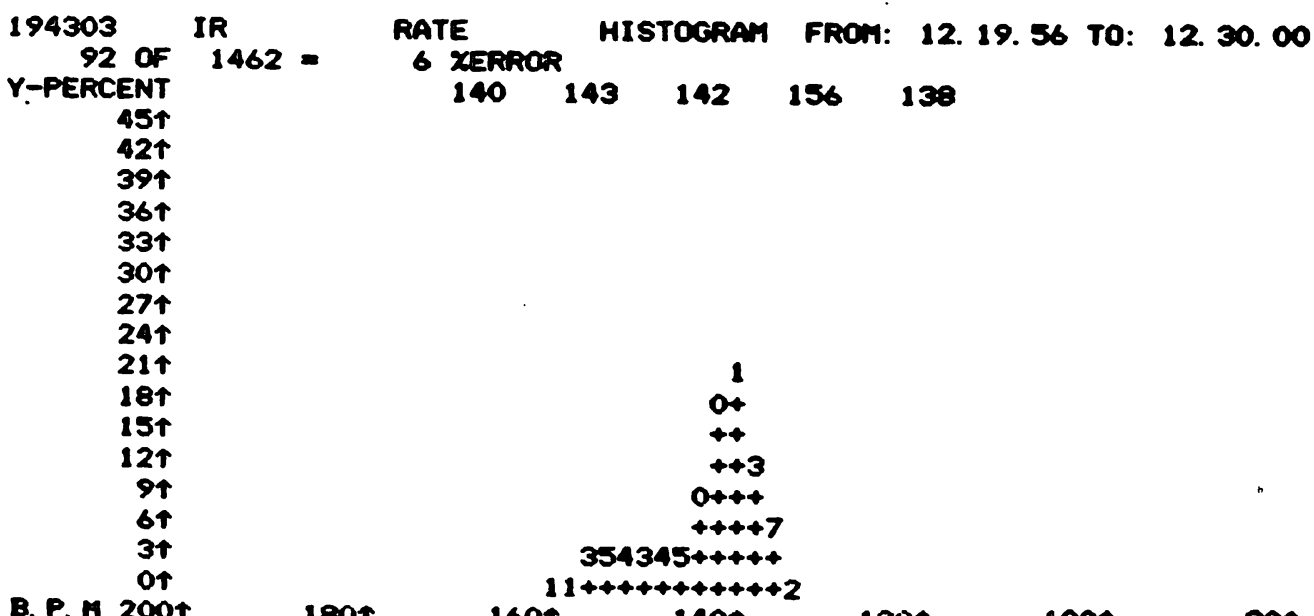

143

14215

138
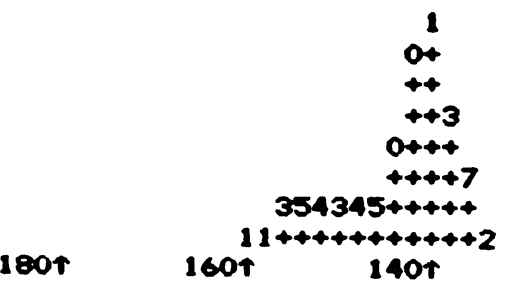

1204

1004

oor

Fig. 2. ACCELERATION ACTIVITY. Epoch 1Q of Fig. 6.

\section{The RATEGRAM display}

Descriptive parameters are presented in the form of a FHR RATEGRAM as shown in Fig. 5.

The $\mathrm{Y}$-axis has a fixed scale with a range of 98 to $182 \mathrm{bpm}$, for example, values in the range 148 to 152 are plotted on the row labelled ' 150 '. Epochs are labelled using a set of 30 characters consisting of the letters $A$ to $Z$ and $\$, !, \%$ and \&, the first epoch is referred to as $1 \mathrm{~A}$, the 31 st epoch as $2 \mathrm{~A}$ and so on.

The modal value of the $\mathrm{RH}$ is plotted under the following rules: -

a) if the Modal Percentage is in the range 36 to 100 per cent, the modal value is plotted as. ' $\mathrm{X}$ ' to indicate that it is a reliable value of baseline. 

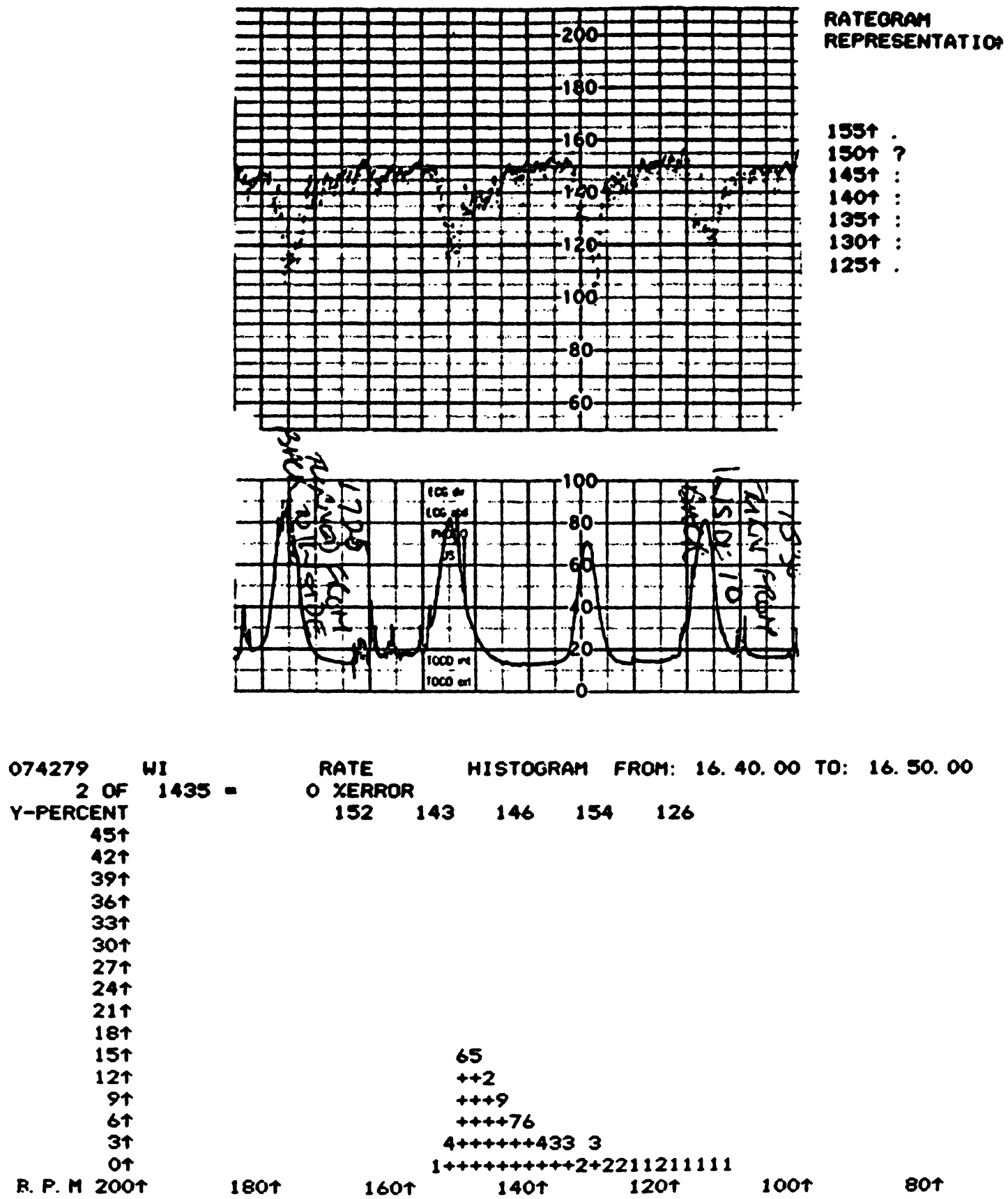

Fig. 3. DECELERATION ACTIVITY. Epoch $1 Y$ of Fig. 5.

b) if the Modal Percentage is in the range 26 to 35 per cent, the modal value is plotted as '?' to indicate that it is only probable that the modal value represents the baseline accurately. c) if the Modal Percentage is less than or equal to 25 per cent, the modal value is not plotted.

The width of the $\mathrm{RH}$ is indicated by plotting colons (:) and fullstops (.) from the 5 th centile value to the 90 th centile value, the number of dots above and below the modal value representing the amount of acceleration and deceleration activity within the epoch.

To allow clearer interpretation, fiducial lines are plotted at 120 and $160 \mathrm{bpm}$, these being limits for baseline bradycardia and tachycardia.

Descriptive parameters are not displayed for an epoch if more than 15 per cent of intervals in the epoch are invalid, instead an asterisk (*) is plotted. 


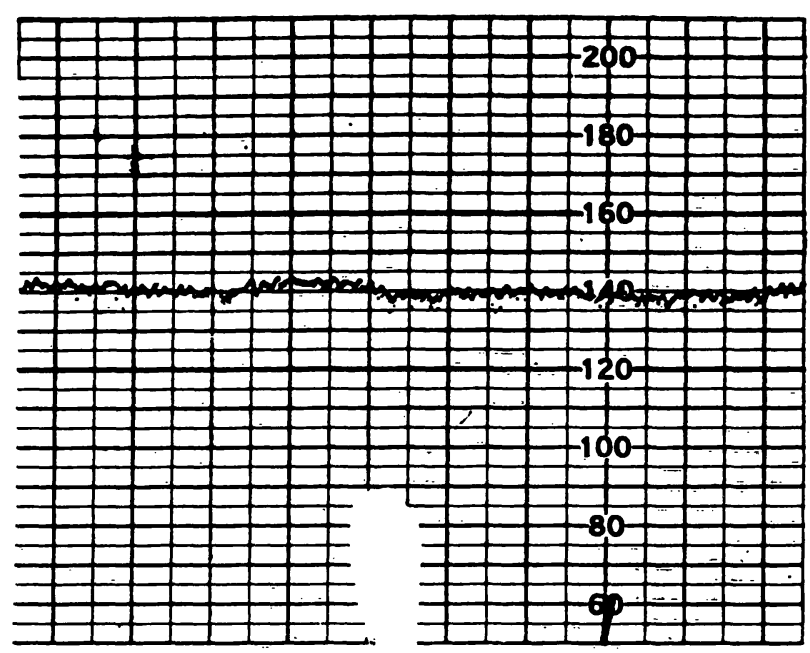

RATECRAM

REPRESENTATION

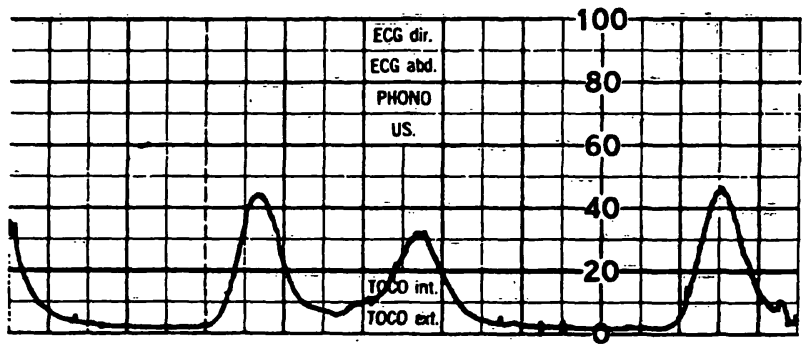

$140+x$

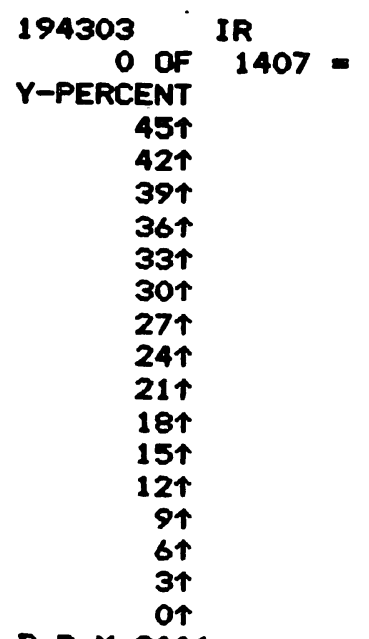

B. P. M 2004

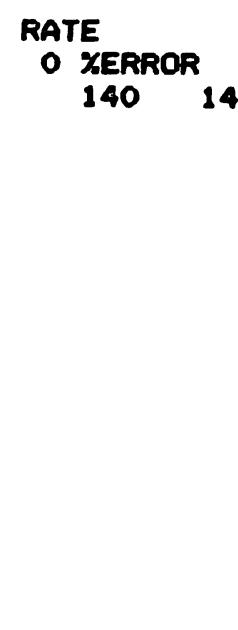

HISTOGRAM FROM: 12.00.00 TO: 12. 10.00

$180 \uparrow$

$160 \uparrow$

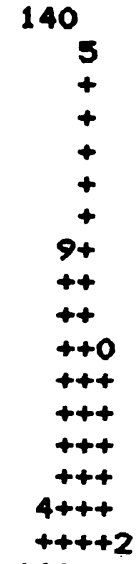

$142 \quad 138$

$120 \uparrow$

$100 \uparrow$

$80 \uparrow$

Fig. 4. REDUCED FHR BASELINE VARIABILITY. Epoch 10 of Fig. 6.

\section{Examples of rategrams}

The type of summary provided by the Rategram is best illustrated by referring to .Rategrams from two labours as shown in Figs. 5 and 6.

NORMAL FHR: epoch 1A, Figs. 1 and 5. From the Rategram, the baseline level is between 143 and $147 \mathrm{bpm}$ and activity is predominantly within the range 140 to $152 \mathrm{bpm}$.

ACCELERATION PATTERN: epoch 1Q, Figs. 2 and 6. From the Rategram, the baseline level is between 138 and $142 \mathrm{bpm}$, and the activity is predominantly acceleration. 


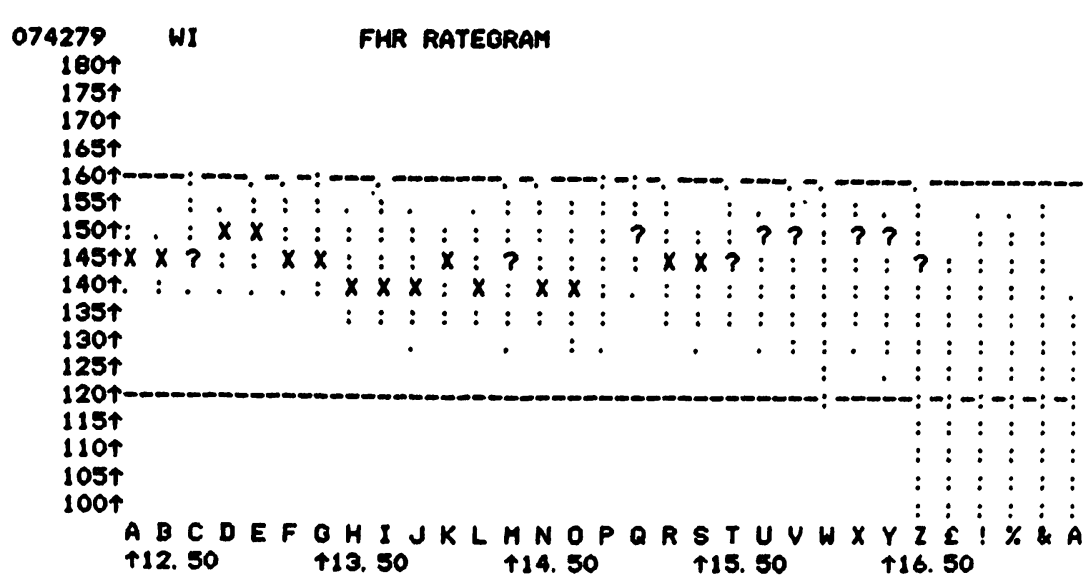

Fig. 5. RATEGRAM for labour W1 074279. Summary of FHR activity during ten minute epochs labelled $1 \mathrm{~A}$ to $2 \mathrm{~A}$. Baseline is marked as ' $\mathrm{X}$ ' in those cases where it is certain and as '?' where it is uncertain. Acceleration activity is indicated by the number of dots above baseline and Deceleration activity as the number of dots below.

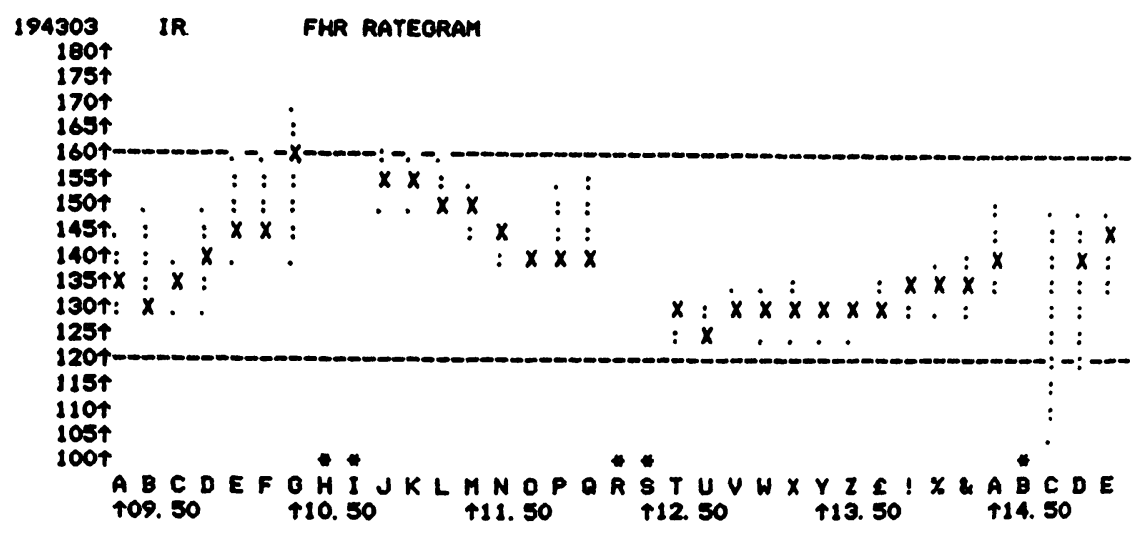

Fig. 6. RATEGRAM for labour IR 194303. Reduced variability is indicated in epochs 10, 1V, 1Y and IZ by the solitary ' $\mathrm{X}$ '. The asterisks $\left(^{*}\right)$ in epochs $1 \mathrm{H}, 1 \mathrm{R}, 1 \mathrm{~S}$ and $2 \mathrm{~B}$ indicate that more than $15 \%$ of beat to beat intervals were invalid.

DECELERATION PATTERN: epoch 1Y. Figs. 3 and 5. From the Rategram, the baseline is an uncertain one, with a value between 148 and 152 bpm. From visual inspection of Fig. 3 this 'baseline' between decelerations. With respect to the calculated baseline the activity is predominantly deceleration.

Epochs in which severe deceleration activity can be inferred are epochs $1 \mathrm{Z}$ to $2 \mathrm{~A}$, in Fig. 5, where the fetus is becoming stressed because of increased uterine activity during the second stage of labour. REDUCED VARIABILITY: epoch 10, Figs. 4 and 6. Reduced variability is indicated by the solitary ' $\mathrm{X}$ ' without any accompanying dots. Reduced variability can also be seen in epochs $1 \mathrm{~V}, 1 \mathrm{Y}$ and $1 Z$.

\section{Rategram assessment}

The performance of the Rategram and the likely data reduction were investigated using a learning set' and a 'test set' of labours, summarised in Tabs. I, II, III, and IV.

Some epochs could not be analysed as the scalpelectrode had become detached or the FECG signal was disturbed during vaginal examination. In addition, some epochs had poor data quality, in that more than $15 \%$ of intervals were invalid. Of the remaining epochs, there were those in which no baseline could be calculated and others in which the baseline was queried.

For clinical purposes, degree of data reduction was evaluated by determining the percentage of clinic- 
Tab. I. 'Test Set' - Results

\begin{tabular}{llllllr}
\hline Patient & $\begin{array}{l}\text { Number } \\
\text { of Epochs }\end{array}$ & $\begin{array}{l}\text { Unana- } \\
\text { lysable } \\
\text { Epochs }\end{array}$ & $\begin{array}{l}\text { Poor } \\
\text { quality } \\
\text { Epochs }\end{array}$ & $\begin{array}{l}\text { No } \\
\text { Baseline }\end{array}$ & $\begin{array}{l}\text { Queried } \\
\text { Baseline }\end{array}$ & $\begin{array}{c}\text { 'Interesting' } \\
\text { Epochs }\end{array}$ \\
\hline 1. AD 351954 & 19 & 0 & 0 & 0 & 1 & $1(5.3 \%)$ \\
2. CO 349611 & 79 & 1 & 0 & 3 & 23 & $12(15.4 \%)$ \\
3. WI 074279 & 42 & 0 & 0 & 7 & 12 & $12(28.6 \%)$ \\
4. WI 229132 & 8 & 0 & 0 & 0 & 2 & $1(12.5 \%)$ \\
5. BI 304269 & 60 & 3 & 2 & 7 & 26 & $12(21.1 \%)$ \\
6. GR 254083 & 75 & 8 & 0 & 5 & 15 & $16(23.9 \%)$ \\
7. OH 344764 & 52 & 0 & 8 & 5 & 19 & $27(51.9 \%)$ \\
8. TO 324592 & 49 & 6 & 2 & 1 & 9 & $10(23.3 \%)$ \\
9. WA 354145 & 88 & 2 & 19 & 8 & 10 & $33(38.4 \%)$ \\
10.CA 355692 & 12 & 0 & 0 & 0 & 2 & $3(25.0 \%)$ \\
1. CO 332164 & 76 & 13 & 0 & 4 & 16 & $14(22.2 \%)$ \\
12. PO 357370 & 44 & 14 & 0 & 1 & 6 & $8(26.7 \%)$ \\
13. DA 247033 & 21 & 5 & 1 & 0 & 0 & $1(6.3 \%)$ \\
14. ME 069537 & 52 & 6 & 0 & 3 & 9 & $2(15.2 \%)$ \\
15. SH 126747 & 27 & 0 & 0 & 0 & 4 & $13(41.9 \%)$ \\
16. ST 361299 & 31 & 0 & 2 & 1 & 3 & $5(18.5 \%)$ \\
17. WI 285536 & 28 & 1 & 0 & 7 & 11 & $8(26.7 \%)$ \\
18. IR 194303 & 35 & 5 & 0 & 1 & 0 & 185 \\
\hline & 798 & 64 & 34 & 53 & 168 & $185 / 734$ \\
\hline
\end{tabular}

ally 'interesting' epochswhich would require clinical action or further processing, whether by visual analysis of the chart recording or some other technique.

The following were chosen as criteria for an interesting' epoch: -

a) An epoch in which there was one or more of the following: moderate or severe deceleration activity, reduced baseline variability, baseline bradycardia or tachycardia.

b) An epoch in which no baseline could be calculated, or the baseline was queried and some activity lay outside the range 120 to $160 \mathrm{bpm}$.

c) An epoch with poor data quality.

Using these criteria $26.6 \%$ of epochs in the learning set and $25.2 \%$ of epochs in the test set were found to be 'interesting'.

The patient with the highest percentage of interesting epochs, patient OH 344764 (Tabs. I and II) had her delivery by caesarean section, one of the reasons for this operative delivery being fetal distress.

When assessing this data reduction it should be realised that the testing technique did not take into account any trend observations, which the Rategram is designed to show. In addition, the majority of labours studied here were induced and/ or stimulated by an oxytocic drug. It can be speculated that these labours are more likely to have fetal distress associated with them than nonstimulated or spontaneous labours.

\section{Discussion}

The POWERGRAM and RATEGRAM, as shown in Fig. 7, provide compact summaries of uterine activity and FHR activity which are relatively easy to generate and display using digital computing techniques. Since results are displayed graphically they can be interpreted by clinical staff who have not been trained in the use of computers.

The POWERGRAM employs Active Pressure Area calculated during a fixed length epoch as a single index of uterine activity. APA does not describe the individual components of uterine contraction such as: intensity, duration, frequency, shape etc. instead it provides an overall quantitative assessment of contraction activity. So long as 
Tab. II. 'Test Set' Clinxal wummary.

\begin{tabular}{|c|c|c|c|c|c|c|c|c|}
\hline$\ldots$ & Pirtily & Induction & Stimulation & $\begin{array}{l}\text { L.about } \\
\text { Length }\end{array}$ & $\begin{array}{l}\text { Mode of } \\
\text { Delivery }\end{array}$ & $\begin{array}{l}\text { Birth } \\
\text { Netght }\end{array}$ & $\begin{array}{l}\text { Apgar } \\
\text { Scores }\end{array}$ & Norl: \\
\hline 1. A1) 3519.54 & 1 & $\begin{array}{l}\text { ARMI+ } \\
\text { Synt }\end{array}$ & Symt. & $7 \mathrm{~h} 36 \mathrm{~m}$ & SVB & $3315 \mathrm{~s}$ & 9.10 & \\
\hline 2. (i) 349611 & D & $\begin{array}{l}\text { ARM+ } \\
\text { Synt }\end{array}$ & Synt. & $15 \mathrm{~h} 3 \mathrm{~m}$ & C/S & $2980 \mathrm{~s}$ & 9.10 & \\
\hline 3. WI 074274 & 3 & $\begin{array}{l}\text { ARM + } \\
\text { Synt. }\end{array}$ & Synt. & $7 h 52 m$ & FORCEPS & $3230 s$ & 9,10 & 1 \\
\hline $\begin{array}{l}\text { 4. WI } 229132 \\
\text { S. BI } 304269\end{array}$ & 1 & $\begin{array}{l}\text { ARMI } \\
\text { ARAI } \\
\text { Synt. }\end{array}$ & $\begin{array}{l}\text { No } \\
\text { Synt. }\end{array}$ & $\begin{array}{l}\ln 27 m \\
9 \mathrm{~h} 45 \mathrm{~m}\end{array}$ & $\begin{array}{l}\text { SVD } \\
\text { SVD }\end{array}$ & $\begin{array}{l}3890 \text { s } \\
3375 s\end{array}$ & $\begin{array}{l}9.10 \\
8.9\end{array}$ & \\
\hline 6. CRR 254083 & 1 & $\begin{array}{l}\text { ARM+ } \\
\text { Synt. }\end{array}$ & Synt. & $11 \mathrm{~h} 34 \mathrm{~m}$ & SVD & 34455 & 9,10 & \\
\hline $\begin{array}{l}\text { 7. OH } 344764 \\
\text { 8. 10 } 324592\end{array}$ & $\begin{array}{l}0 \\
2\end{array}$ & $\begin{array}{l}\text { N() } \\
\text { ARAI+ } \\
\text { Synt. }\end{array}$ & $\begin{array}{l}\text { Synt. } \\
\text { Synt. }\end{array}$ & $\begin{array}{l}15 h 42 \mathrm{~m} \\
7 \mathrm{~h} 57 \mathrm{~m}\end{array}$ & $\begin{array}{l}\text { C/S } \\
\text { SVD }\end{array}$ & $\begin{array}{l}3830 \\
3445 s\end{array}$ & $\begin{array}{l}9.10 \\
9.10\end{array}$ & $\begin{array}{l}2 \\
1\end{array}$ \\
\hline 9. WA 354145 & 0 & $\begin{array}{l}\text { AKM } \\
\text { Synt. }\end{array}$ & Synt. & $14 \mathrm{~h} 9 \mathrm{~m}$ & HORCFPS & 3275 & 9.9 & 1 \\
\hline 10. ('A 355692 & $\mathbf{0}$ & $\begin{array}{l}\text { AR:I+ } \\
\text { Synt. }\end{array}$ & Synt. & $12 \mathrm{hs} 2 \mathrm{~m}$ & Cis & $3860 \mathrm{~s}$ & 9.9 & 3 \\
\hline $11 .(1) 332164$ & 0 & $\begin{array}{l}\text { ARMI+ } \\
\text { Synt. }\end{array}$ & Synt. & $12 \mathrm{~h} 40 \mathrm{~m}$ & C/S & 2960s & 9.9 & 3 \\
\hline $\begin{array}{l}\text { 12. PO } 357370 \\
\text { 13. DA } 247033\end{array}$ & $\begin{array}{l}0 \\
1\end{array}$ & $\begin{array}{l}\text { ARM } \\
\text { ARMI+ } \\
\text { Synt. }\end{array}$ & $\begin{array}{l}\text { NO } \\
\text { Synt. }\end{array}$ & $\begin{array}{l}7 h+2 m \\
2 h 23 m\end{array}$ & $\begin{array}{l}\text { FORCLPS } \\
\text { SVD }\end{array}$ & $\begin{array}{l}3975 \mathrm{~s} \\
3715 \mathrm{~s}\end{array}$ & $\begin{array}{l}9.10 \\
7.9\end{array}$ & \\
\hline $\begin{array}{l}\text { 14. ME } 069537 \\
\text { 15. SH } 126747\end{array}$ & $\begin{array}{l}0 \\
1\end{array}$ & $\begin{array}{l}\text { ARMI } \\
\text { ARMt } \\
\text { Synt. }\end{array}$ & $\begin{array}{l}\text { Synt. } \\
\text { Synt. }\end{array}$ & $\begin{array}{l}9 \mathrm{hl} 2 \mathrm{~m} \\
3 \mathrm{~h} 48 \mathrm{~m}\end{array}$ & $\begin{array}{l}C \text { 'S } \\
\text { SVD }\end{array}$ & $\begin{array}{l}3900 \mathrm{~s} \\
3830 \mathrm{~s}\end{array}$ & $\begin{array}{l}\text { 3. } 4 \\
\text { 7. } 9\end{array}$ & \\
\hline $\begin{array}{ll}\text { 16. ST } & 361299 \\
\text { 17. IVI } & 285536 \\
\text { 18. IR } & 194303\end{array}$ & $\begin{array}{l}0 \\
1 \\
0\end{array}$ & $\begin{array}{l}\text { NO } \\
\text { NO } \\
\text { NO }\end{array}$ & $\begin{array}{l}\text { Synt. } \\
\text { Synt. } \\
\text { NO }\end{array}$ & $\begin{array}{l}12 \mathrm{~h} 2 \mathrm{~m} \\
13 \mathrm{~h} 33 \mathrm{~m} \\
14 \mathrm{~h} 46 \mathrm{~m}\end{array}$ & $\begin{array}{l}\text { FORCEPS } \\
\text { SVD } \\
\text { FORCEPS }\end{array}$ & $\begin{array}{l}2980 \mathrm{~s} \\
3660 \mathrm{~s} \\
4345 \mathrm{~s}\end{array}$ & $\begin{array}{l}9,9 \\
6,9 \\
8,9\end{array}$ & \\
\hline
\end{tabular}

ARM = Artificial Rupture of Membranes. Synt. = Syntocinon, Labour Length $=$ Midwife's assessment of first and second stages. SVD = Spontaneous Vertex Delivery. $C / S=$ Caesarian Section, Apgar Scores are at 1 and 5 minutes after delivery.

NOTE 1: Meconium present

2: C/S for Fetal Distress, Failure to Progress.

3: C/S for Fetal Distress, Failure to Progress and Disproportion.

Tab. III. 'Learning Set' - Results.

\begin{tabular}{lllllll}
\hline Patient & $\begin{array}{l}\text { Number } \\
\text { of Epochs }\end{array}$ & $\begin{array}{l}\text { Unanalysable } \\
\text { Epochs }\end{array}$ & $\begin{array}{l}\text { Poor quality } \\
\text { Epochs }\end{array}$ & No Baseline & $\begin{array}{l}\text { Queried } \\
\text { Baseline }\end{array}$ & $\begin{array}{l}\text { 'Interesting' } \\
\text { Epochs }\end{array}$ \\
\hline 1. CA 368971 & 22 & 0 & 0 & 0 & 0 & $1(4.5 \%)$ \\
2. DU 322447 & 14 & 0 & 2 & 0 & 1 & $4(28.6 \%)$ \\
3. FA 322633 & 22 & 0 & 2 & 0 & 2 & $3(13.6 \%)$ \\
4. MA 304995 & 31 & 3 & 1 & 1 & 1 & $6(21.4 \%)$ \\
5. MC 357433 & 20 & 0 & 11 & 9 & 13 & $24(42.1 \%)$ \\
6. MO 324799 & 58 & 1 & 20 & 1 & 7 & $36(30.3 \%)$ \\
7. TA 359447 & 126 & 7 & 36 & 12 & 32 & 75 \\
\hline & 293 & 11 & $36 / 282$ & $12 / 246$ & $32 / 246$ & $75 / 282$ \\
& & $11 / 293$ & $(12.8 \%)$ & $(4.9 \%)$ & $(13.0 \%)$ & $(26.6 \%)$ \\
\hline
\end{tabular}


Tab. IV. 'Learnins Set' - Clinical summary.

\begin{tabular}{|c|c|c|c|c|c|c|c|c|}
\hline Patient & Parity & Induction & Stimulation & $\begin{array}{l}\text { Labour } \\
\text { Length }\end{array}$ & $\begin{array}{l}\text { Mode of } \\
\text { Delivery }\end{array}$ & $\begin{array}{l}\text { Birth } \\
\text { Weight }\end{array}$ & $\begin{array}{l}\text { Apgar } \\
\text { Scores }\end{array}$ & NOTE \\
\hline 1. CA 368971 & 0 & $\begin{array}{l}\text { ARM+ } \\
\text { Synt. }\end{array}$ & Synt. & $3 \mathrm{~h} 30 \mathrm{~m}$ & $\mathrm{C} / \mathrm{S}$ & $3130 \mathrm{~s}$ & 8,10 & \\
\hline 2. DU 322447 & 1 & $\begin{array}{l}\text { ARM+ } \\
\text { Synt. }\end{array}$ & Synt. & $1 \mathrm{~h} 2 \mathrm{~m}$ & SVD & $3490 \mathrm{~s}$ & 9,10 & \\
\hline 3. FA 322633 & 1 & $\begin{array}{l}\text { ARM+ } \\
\text { Synt. }\end{array}$ & Synt. & $6 \mathrm{~h} 14 \mathrm{~m}$ & SVD & $4375 s$ & 6,8 & \\
\hline 4. MA- 304995 & 1 & $\begin{array}{l}\text { ARM+ } \\
\text { Synt. }\end{array}$ & Synt. & $8 \mathrm{~h} 34 \mathrm{~m}$ & SVD & $3115 \mathrm{~s}$ & 9,10 & \\
\hline 5. MC 357433 & 1 & $\begin{array}{l}\text { ARM+ } \\
\text { Synt. }\end{array}$ & Synt. & $3 \mathrm{~h} 14 \mathrm{~m}$ & SVD & $3215 \mathrm{~s}$ & 9,10 & \\
\hline $\begin{array}{l}\text { 6. MO } 324799 \\
\text { 7. TA } 359447\end{array}$ & $\begin{array}{l}0 \\
1\end{array}$ & $\begin{array}{l}\text { ARM } \\
\text { NO }\end{array}$ & $\begin{array}{l}\text { Synt. } \\
\text { Synt. }\end{array}$ & $\begin{array}{r}6 \mathrm{~h} 34 \mathrm{~m} \\
21 \mathrm{~h} 53 \mathrm{~m}\end{array}$ & $\begin{array}{l}\text { C/S } \\
\text { FORCEPS }\end{array}$ & $\begin{array}{l}2930 \mathrm{~s} \\
3460 \mathrm{~s}\end{array}$ & $\begin{array}{l}9,9 \\
9,9\end{array}$ & 1 \\
\hline
\end{tabular}

ARM = Artificial Rupture of Membranes, Synt. = Syntocinon, Labour Lensth = Midwife's assessment of first and second stages. SVD = Spontaneou Vertex Delivery, $\mathrm{C} / \mathrm{S}=$ Caesarian Section, Apgar Scores are at 1 and 5 minutes after delivery.

NOTE 1: Twin delivery

changes in contraction components have a parallel relationship then APA accurately reflects uterine activity. However, if for instance contraction intensity was to increase while contraction duration decreased, APA could give misleading results. This however has not been a problem clinically.

The RATEGRAM uses a more complex presentation to indicate changes and trends in FHR activity. For clinical purposes, those aspects of FHR activity which are more important are: the level and trend of baseline FHR; the occurrence of transient accelerations; the occurrence of transient decelerations; the occurrence of reduced baseline variability and poor data quality. The RATEGRAM has been shown to give an accurate and concise representation of these aspects.

However, there are limitations. Generation of a Rate Histogram destroys the timing relationships of the data, for instance an epoch containing several narrow decelerations can have the same representation as an epoch containing a single wide deceleration. Use of a fixed length epoch means that reduced baseline variability lasting for less than ten minutes can be missed. In addition, the method is also susceptible to abrupt changes in baseline during an epoch, this problem is catered for by the baseline validation described in section 5 .

The RATEGRAM is intended to provide an overview of FHR activity without the need to scrutinise metrês of chart recording. On average a four fold reduction in the amount of pen tracing requiring a close clinical appraisal can be achieved.

\section{Conclusions}

From a clinical point of view:

- The rategram provides an accurate and concise summary of the various components of FHR activity in a way which allows ominous portions of FHR activity to be identified. In addition, it allows visualisation of trends in activity which are too slow to be noticed in chart recordings.

- By defining criteria for a clinically 'interesting' epoch it was shown that only $25 \%$ of epochs in the labours studied were 'interesting' and hence required further study or action. The majority of these labors were induced and/or stimulated by an oxytocic drug.

- It can be suggested that the use of data reduction and presentation techniques, such as the rategram, can achieve a four-fold reduction in the amount of pen tracing requiring close clinical appraisal.

- The powergram and rategram together, as shown in Fig. 7, provide summaries of uterine activity and FHR activity which, although quantitat- 

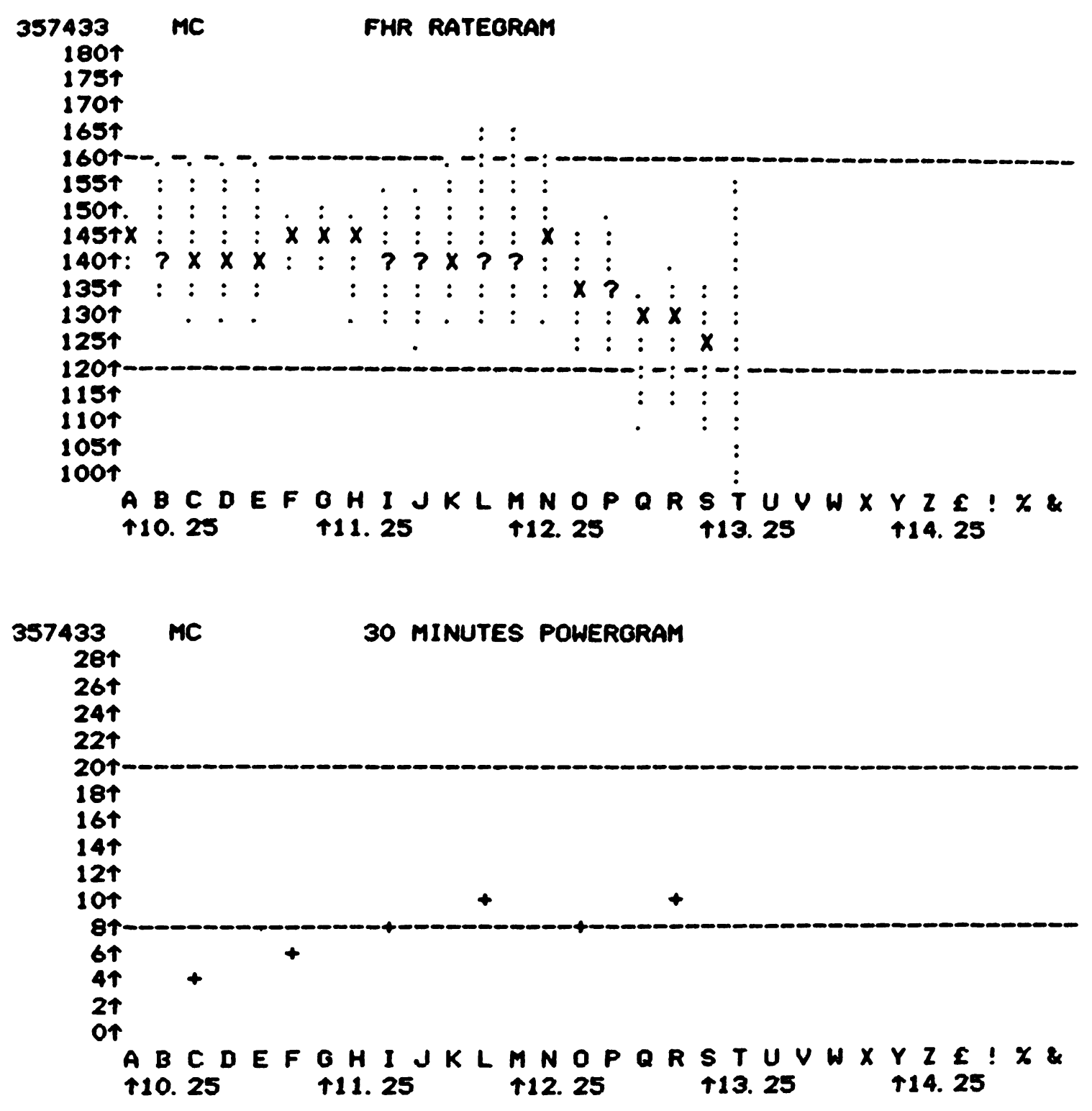

Fig. 7. RATEGRAM and POWERGRAM for labor. MC 357433.

ively derived can be interpreted more qualitatively if desired.

From a more technical point of view:-

- The software ratemeter is designed to adapt to the changing FECG signal and allows data quality analysis by the computer, so that results are only presented for those epochs having reasonable data quality.

\section{Summary}

This paper describes a computing technique which allows large quantities of Fetal Heart Rate (FHR) data to be reduced to a concise summary of the various components
- The technique does not require large amounts of storage nor processing power and hence can be implemented for real-time monitoring.

- Although the rategram employs graphical presentation it can be implemented using relatively simple, low resolution alphanumeric output devices. of FHR variation. This summary, termed a RATEGRAM, was designed for clinical use in conjunction with the Powergram, as shown in Fig. 7. 
The first part of the processing is calculation of beat to beat intervals (measured in milliseconds) from the fetal ECG signal by a program known as the SOFTWARE RATEMETER. The Software Ratemeter detects the Rwave peak of the ECG complex by adjusting an amplitude threshold in response to changes in amplitude and signal to noise ratio $(\mathrm{S} / \mathrm{N})$ of the signal. In addition, the authenticity of each beat to beat interval is validated, artefactual ones rejected and data quality assessed so that subsequent processing is not performed on poor quality data.

Data reduction is based on generation of the RATE HISTOGRAM (RH) which contains the distribution of FHR during a ten minute epoch. Examples of Rate Histograms in Figs. 1 to 4 demonstrate that the RH accurately reflects the components of FHR activity.

By plotting several descriptive parameters of the $R H$, epoch by epoch, a summary known as the RATEGRAM can be displayed, as shown in Figs. 5 and 6, which allows such components as: Baseline FHR level, Acceleration Activity, Deceleration Activity and Baseline Variability to be assessed. Baseline FHR level is plotted as an ' $\mathrm{X}$ ' in those cases where it is certain, as a '?' where it is uncertain and is not plotted when there is no baseline. The amount of acceleration and deceleration activity is indicated by the number of dots (.) above and below the baseline level.
Occurrence of reduced baseline, variability is indicated by a X without accompanying dots.

The performance of the Rategram and the likely data reduction were investigated using a 'learning set' of 7 labours and 'test set' of 18 labours consisting of a total of 1091 ten minute epochs, (approximately 182 hours) as detailed in Tabs. I, II, III and IV. The majority of these labours were induced and/or augmented using oxytocic drugs.

An 'interesting' epoch, that is, one which required further clinical action or study, was defined as one in which one or more of the following occurred: moderate or severe deceleration activity, reduced baseline variability, baseline bradycardia or tachycardia. Also included were those epochs where data quality was poor or a baseline could not be accurately defined.

The number of interesting epochs within individual labours are detailed in Figs. 1 and 3, overall 25 per cent of epochs were clinically interesting and required further study or action.

In conclusion, it is suggested that the use of data reduction and presentation techniques, such as the Rategram, can highlight areas of clinically interesting FHR activity and can achieve a four-fold reduction in the amount of pen tracing requiring close clinical appraisal.

\section{Keywords: Computing techniques, data quality, data reduction, descriptive parameters, fetal heart rate, rategram, rate histogram, software ratemeter.}

\section{Zusammenfassung}

Komputertechniken für die Reduktion physiologischer Daten sub partu. II. Fetale Herzfrequenz

Diese Arbeit beschreibt ein Rechnerprogramm, das es erlaubt, große Mengen fetaler Herzfrequenzdaten auf eine kurze und präzise Zusammenfassung der verschiedenen Komponenten der fetalen Herzfrequenzvariabilität zu reduzieren. Diese Zusammenfassung, 'RATEGRAMM' genannt, wurde in Verbindung mit dem 'POWERGRAMM' für den klinischen Gebrauch entworfen (s. Fig. 7).

Der erste Teil der Verarbeitung besteht in der Berechnung der Schlag-zu-Schlag-Intervalle (gemessen in Millisekunden) der fetalen EKG-Signale durch eine Routine, die 'RATEMETER' heißt. 'RATEMETER' erkennt den R-Zackengipfel eines EKG-Komplexes indem es in Abhängigkeit von den Amplitudenveränderungen und der Signal-/Störimpuls-ratio des Ausgangssignales einen Amplitudengrenzwert generiert und anpaßt. Zusätzlich wird die Echtheit jedes Schlag-zu-Schlag-Intervalles geprüft, Artefakte unterdrückt und dergestalt die Datenqualität festgelegt, so daß eine nachfolgende Prüfung bei schlechter Datenqualität nicht vorgenommen werden muß. Die Datenreduktion basiert auf der Erstellung eines 'Ratehistogramms' (RH), das die Verteilung der fetalen.Herzfrequenzimpulse während eines Zeitintervalles von 10 Minuten enthält. Beispiele von Rate-Histogrammen (in den Fig. 1-4) zeigen, daß diese genau die Komponenten der fetalen Herzfrequenzaktivität wiedergeben. Eine Zusammenfassung, genannt 'Rategramm' kann ausgegeben werden (wie in Fig. $5+6$ ) indem verschiedene, beschreibende Parameter des Ratehistogramms Zeitintervall für Zeitintervall aus- gedruckt werden. Folgende Teilaspekte sind darstellbar: Basislinien, Niveau der fetalen Herzfrequenz, Akzelerationsaktivität, Dezelerationsaktivität und BasislinienVariabilität. Die basale, fetale Herzfrequenz wird mit einem ' $X$ ' ausgedruckt in jenen Fällen, in denen sie irrtumsfrei vorliegt und mit einen '?' in jenen, wo sie ungewiß ist; sie wird nicht ausgedruckt, wenn sie fehlt. Die Akzelerations- und Dezelerationsaktivität wird durch die Anzahl der Punkte (.) oberhalb und unterhalb des Basislinienniveaus angegeben. Das Auftreten einer reduzierten Basislinienvariabilität wird mit einem ' $\mathrm{X}$ ' ohne nachfolgende Punkte (.) dargestellt. Die Arbeitsweise des Rategramms und die Datenreduktion wurden getestet unter Verwendung eines 'Lern-sets' von $7 \mathrm{Ge}$ burten und eines 'Testsets' von 18 Geburten, die insgesamt aus 1091 10-Minuten-Epochen (ungefähr 182 Stunden) bestanden. (Detaillierte Angaben in Tab. I, II, III, IV). Die Mehrzahl dieser Geburten waren induziert und/oder stimuliert unter Verwendung von Oxytocica.

Als ,interessantes“ Zeitintervall, d.h. ein Intervall, das weiteres klinisches Handeln oder eine Begutachtung verlangte, wurde eine Zeitspanne definiert, in der eines oder mehrere der folgenden Merkmale auftraten: mittelschwere oder schwere Dezelerationsaktivität, reduzierte Basislinienvariabilität, Basislinienbradykard ia oder Basislinientachycardie. Dazu gehörten auch jene Intervalle, in denen die Datenqualität schlecht war oder in denen die Basislinie nicht sauber definiert werden konnte. Die Anzahl der 'interessanten Intervalle' innerhalb einer individuellen Geburt sind detailliert in Fig. 1 und 3 angegeben. 
Insgesamt $25 \%$ der Intervalle waren klinisch interessant und benötigten weitere Begutachtung oder Maßnahmen.

Zusammenfassend wird vermutet, daß der Einsatz der Datenreduktion und der Darstellungstechnik, wie z.B. das Rategramm, klinisch interessante Phasen fetaler Herz- frequenzaktivität klar erkennen kann und daß eine vielfache Reduktion der Registrierpapiermenge, die einer sorgfältigen klinischen Beurteilung bedarf, erzielt werden kann.

Schlüsselwörter: Datenqualität, Datenreduktion, descriptive Parameter, fetale Herzfrequenz, Komputertechniken, Rategramm, Ratehistogramm, Sof tware Ratemeter.

\section{Résumé}

«Techniques de calcul pour la réduction des donnés physiologiques intrapartum ... II' Fréquence cardiaque , foetale»

Cet article décrit une technique de calcul destinée à réduire d'importantes quantités de données concernant le rythme cardiaque foetal (RCF) en un résumé concis des divers constituants de la variation de rythme. Ce résumé, appelé ry thmogramme, a été établi pour une utilisation clinique, en association avec le "powergram», comme indiqué sur la Figure 7.

La première partie du traitement est le calcul, à partir du signal électrocardiographique des intervalles de battement à battement, par utilisation d'un programme dénommé «logiciel de mesure du rythme». Celui-ci détecte les sommets des ondes $R$ en ajustant son seuil d'amplitude en fonction des variations d'amplitude du signal et du rapport signal/bruit.

De plus l'authenticité de chaque intervalle est validée, les artefacts rejetés, et la qualité de l'information contrôlée, de manière à ce que le traitement ultérieur ne soit pas entrepris sur des données incertaines. La réduction de données est fondée sur la réalisation d'un histogramme de rythme qui représente la distribution des valeurs du RCF pendant une période de 10 minutes. Les exemples de tels histogrammes (Fig. 1 à 4) montrent bien qu'ils correspondent exactement aux éléments constituant le RCF.

En groupant plusieurs paramètres descriptifs de l'histogramme de rythme, période par période, un résumé, dénommé le rythmogramme, peut être construit (voir Fig. 5 et 5 ), qui révèle des paramètres tels que: la ligne de base, les accélérations, les décélérations et la variabilité.

La ligne de base est indiquée par un «X» lorsqu'elle est certaine, un? lorsqu'elle est incertaine, et n'est pas marquée lorsqu'elle n'existe pas.
La quantité d'accélération et de décélération est/indiquée par le nombre de points au-dessus et au-dessous de la ligne de base.

La survenue d'une réduction de la variabilité est indiquée par un $\mathrm{X}$ non accompagnée de points.

L'intérêt du rythmogramme et la validité de la réduction de données furent étudiés en les appliquant à un groupe de 7 cas de travail didactique et à un groupe de 18 cas de travail témoin, représentant au total 1091 périodes de 10 minutes (environ 182 heures) (voir tabs. I, II, III, IV). La plupart de ces cas correspondaient à des déclenchements du travail ou à des stimulations par agents ocytociques.

Une période fut considérée comme intéressante, et requérant une action clinique ou une étude particulière, lorsqu'on y observa: soit des décélérations modérées ou sévères, soit une réduction de la variabilité, soit une bradycardie ou une tachycardie, ou une combinaison de ces phénomènes.

Furent également incluses les périodes où la qualité des données fut médiocre et où la ligne de base ne put être déterminée avec précision.

Les nombres de périodes intéressantes pour chaque cas individuel sont détaillés dans les figures 1 et 3 . Globalement $25 \%$ de périodes furent intéressantes cliniquement. On conclut de cette étude que l'utilisation des méthodes de réduction de données et de techniques de présentation, telles que le rythmogramme, peut éclairer la compréhension de segments cliniquement intéressants du RCF et réduire par un facteur 4 la quantité d'enregistrement requérant une analyse clinique attentive.

Mots-clés: Informatique, histogramme de rythme, logiciel de mesure de rythme, ordinateur, paramètres descriptifs rythmogramme, réduction de données, rythme cardiaque foetal, validité de données.

Acknowledgements: The authors gratefully acknowledge the financial support of the Scottish Home and Health Department, also the assistance of Miss W. L. BARRIE in the preparation of this paper. 


\section{Bibliography}

[1] BEGUIN, F., S. Y. YEH, A. FORSYTHE, E. H. HON: A study of fetal heart rate deceleration areas. II Correlation between deceleration area and fetal pH during labour. Obstet. and Gynec. 45 (1975) 292

[2] CALDEYRO-BARCIA, R., C. MENDEZ-BAUER, J. POSEIRO, L. A. ESCARCENA, S. V. POSE, J. BIENIARZ, I. ARNT, L. GULIN, O. AlthaBE: Control of human FHR during labour. In: CASSELS, D. E.: The heart and circulation in the newborn and infant. Grune and Stratton, New York 1966

[3] CHIK, L., M. G. ROSEN, V. J. HIRSCH, R. J. SOKOL: Programmed identification of FHR deceleration patterns. Amer. J. Obstet. Gynec. 119 (1974) 6

[4] DEHAAN, J., J.H. VAN BEMMEL, L. A. M. STOLTE, J. JANSSENS, T. K. A. B. ESKES, B. VERSTEEG, A. F. L. VETH: Quantitative evaluation of Fetal Heart Rate patterns. III Beat-to-Beat arrhythmia. Europ. J. Obstet. Gynec. 4 (1971) 137

[5] FLOWERS, C. E., C. M. HIN KLEY, J. W. HATCHER: The use of a digital computer in monitoring the condition of the fetus during labour. Amer. J. Obstet. Gynec. 111 (1971) 644

[6] GIBBONS, D. T., F. JOHNSON: An intelligent foetal monitor. Systems International 5 (1977) 66
[7] HON, E. H., E. J. QUILLIGAN : The classification of FHR: II A revised working classification. Connecticut Medicine 31 (1967) 779

[8] MORGENSTERN, J., H. ALBR̃ECHT, J. BOKELMANN, H. SCHMIDT: Computed dip-parameters derived from digitized FHR-curves. I. The describing parameters and the method of digitizing. J. Perinat. Med. 2 (1974) 254

[9] OTT, W. J.: The current status of intrapartum fetal monitoring. Obstet. Gynecol. Surv. 31 (1976) 339

[10] SIMBORG, D. W., R. S. ROSS, K. B. LEWIS, R. H. SHEPARD: The R-R interval histogram. JAMA 197 (1966) 145

[11] TOURNAIRE, M., S. Y. YEH, A. FORSYTHE, E. H. HON: A study of fetal heart rate deceleration areas. I. Preliminary exploration. Obstet. and Gynec. 42 (1973) 711

[12] TOURNAIRE, M., G. STURboIS, A. RIPOCHE, R. LE HOUEZEC, G. BREART, J. CHAVINIE, C. Sureau: Evaluation of the fetal state by automatic analysis of the heart rate. II. Deceleration areas and umbilical artery blood pH. J. Perinat. Med. 4 (1976) 118

Received May 25, 1978. Accepted September 15, 1978.

M. J. Henry B.Sc.

Obstetric Computing Laboratory

Ninewells Hospital and Medical School

Dundee, Scotland DD1 9SY 